\title{
Efektifitas layanan penguasaan konten menggunakan metode problem solving untuk meningkatkan self regulated learning siswa
}

\author{
Winda Yola Agustian 1, Firman 2, Zikra 3 \\ ${ }^{123}$ Universitas Negeri Padang \\ *Corresponding author, e-mail: wyabahkri07@gmail.com
}

\begin{abstract}
Abstrak
Self Regulated Learning merupakan kemampuan siswa mengatur diri dalam belajar . Salah satu upaya yang dilakukan oleh guru BK untuk meningkatkan self regulated learning siswa yaitu melalui layanan penguasaan konten. Namun pada kenyataannya, upaya yang diberikan oleh guru BK secara belum mencapai sasaran sesuai yang diharapkan. Penelitian ini bertujuan melihat efektifitas layanan penguasaan konten menggunakan metode problem solving untuk meningkatkan self regulated learning siswa dalam belajar di sekolah.

Penelitian ini menggunakan pendekatan kuantitatif. Jenis penelitian ini adalah Quasi Eksperiment rancangan The Non Equivalent Countrol Group. Subjek penelitian adalah siswa kelas XI IPS 2 dan XI IPS 3 SMAN 7 Padang. Teknik pengumpulan data menggunakan kuisioner, kemudian dianalisis dengan teknik uji beda ( $t$-test) menggunakan bantuan program Statistical Product and Service Solution (SPSS) versi 20.0 dan Microsoft Excell 2007.Temuan penelitian ini mengungkapkan: (1) terdapat perbedaan yang signifikan pada self regulated learning siswa kelompok eksperimen sebelum dan sesudah diberikan layanan penguasaan konten menggunakan metode problem solving (2) tidak terdapat perbedaan yang signifikan pada self regulated learning siswa kelompok kontrol sebelum dan sesudah diberikan layanan penguasaan konten tanpa menggunakan metode problem solving (3) terdapat perbedaan yang signifikan pada self regulated learning siswa antara kelompok eksperimen yang mengikuti layanan penguasaan konten menggunakan metode problem solving dan self regulated learning siswa kelompok kontrol yang mengikuti layanan penguasaan konten tanpa menggunakan metode problem solving
\end{abstract}

Kata Kunci: layanan penguasaan konten, problem solving, self regulated learning.

How to Cite: Winda Yola Agustian 1, Firman 2, Zikra 3. 2018. Efektifitas layanan penguasaan konten menggunakan metode problem solving untuk meningkatkan self regulated learning. Konselor, VV (N): pp. XX-XX, DOI:10.24036/XXXXXXXXXX-X-XX

This is an open access article distributed under the Creative Commons 4.0 Attribution License, which permits unrestricted use, distribution, and reproduction in any medium, provided the original work is properly cited. (O2017 by author and Universitas Negeri Padang.

\section{Pendahuluan}

Belajar merupakan kegiatan yang pentinng bagi setiap individu dalam perubahan tingkalaku bahkan setiap saat dalam kehidupan sehari-hari manusia selalu mengalami proses belajar. Menurut Syaiful Bahri Djamarah(2011:13) " belajar adalah serangkaian kegiatan jiwa raga untuk memperoleh sesuatu perubahan tingkah laku sebagai hasil dari pengalaman individu dalam interaksi dengan lingkungannya, yang menyangkut kognitif, afektif, dan Psikomotor". Sementara itu menurut Uno (2007:16) belajar merupakan perubahan perilaku yang terjadi setelah siswa mengikuti atau mengalami suatu proses pembelajaran. Jadi, belajar adalah perubahan tingkah laku yang terjadi pada individu berdasarkan pengalaman.

Ada banyak faktor yang mempengaruhi kebiasaan belajar. menurut Djaali (2015:128) "kebiasaan belajar dapat diartikan sebagai cara atau teknik yang menetap pada diri siswa pada waktu menerima pelajaran, membaca buku, mengerjakan tugas, dan pengaturan waktu untuk menyelesaikan kegiatan. Kebiasaan belajar yang baik dapat dimilki siswa melalui kemampuan untuk meregulasi dirinya. Kemampuan ini dikenal dengan istilah self regulation.

Shunk (1998) mengemukakan bahwa siswa dikatakan melakukan Self Regulation dalam belajar bila mereka secara sistematis mengatur perilaku dan kognisinya dengan memperhatikan aturan yang dibuat sendiri, mengontrol berjalannya suatu proses belajar dan mengintegrasikan pengetahuan, melatih untuk mengingat informasi yang di peroleh, serta mengembangkan dan mempertahan nilai - nilai positif belajarnya.

Menurut Wine ( dalam Handy Susanto, 2006) setiap orang akan berusaha untuk meregulasi fungsi dirinya dengan berbagai cara dalam mencapai tujuan yang telah ditetapkan. Apabila siswa mampu mengembangkan self regulation secara optimal, maka pencapaian tujuan yang telah ditetapkan dapat 
dicapai secara optimal. Sebaiknya, pada saat siswa kurang mampu mengembangkan self regulation dalam dirinya, maka pencapaian tujuan yang telah ditetapkan tidak dapat dicapai secara optimal. Sellf regulation dalam belajar dikenal dengan istilah self regulated learning.

Self regulated learning menekankan pentingnya inisiaif karena self regulated learning merupakan belajar yang terjadi atas dasar inisiatif. Siswa yang memiliki inisiatif menunjukan kemampuan untuk menggunakan pemikiran, perasaan, strategi dan tingkah lakunya yang ditunjukan untuk mencapai tujuan ( Zimmerman, 2002).

Self-Regulated Learning adalah kemampuan siswa mengatur diri dalam belajar. Winne ( dalam Santrock, 2007) Self regulated learning adalah kemampuan untuk memunculkan dan memonitor sendiri pikiran, perasaan, dan perilaku untuk mencapai suatu tujuan. Tujuan ini berupa tujuan akademik ( meningkatkan pemahaman dalam membaca, menjadi penulis yang baik, belajar perkalian, mengajukan pertanyaan yang relevan), mampun tujuan sosio-emosional (mengontrol kemarahan, belajar akrab dengan teman sebaya).

Lebih lanjut zimmerman (2004) mendefenisikan self regulated learning sebagai kemampuan siswa untuk berpartisipasi aktif dalam proses belajarnya, baik secara metakognitif, individu yang meregulasi diri merencanakan, mengorganisasi, mengintruksi diri, memonitor dan mengevaluasi dirinya dalam proses belajar. Secara motivasional dan secara behavioral. Secara metakognitif individu yang belajar merasa bahwa dirinya kompeten, memiliki keyakinan diri (self efficacy) dan memiliki kemandirian sedangkan secara behavioral, individu yang belajar menyeleksi, menyusun, dan menata lingkungan agar optimal dalam belajar.

Namun, fenomena yang terjadi saat ini sangat berbeda khususnya terlihat pada kebiasaan siswa dalam belajar. seperti hasil penelitian Irma (2014) menunjukkan sebanyak $41,70 \%$ subjek penelitian memiliki selfregulated learning yang rendah. Selanjutnya, hasil penelitian Alsa (2005) menunjukkan lemahnya kema mpuan regulasi diri siswa dalam belajar matematika. Hasil penelitian Mutya Marantika (2015) menyatakan sebagian besar Siswa memilki self regulated learning berada pada kategori cukup baik dengan persentase $34,8 \%$. Adapun penjelasannya, self regulated learning siswa pada aspek strategi regulasi kognitif berkategori kurang baik yaitu $42 \%$. Selanjutnya pada aspek strategi regulasi motivasi berkategori cukup baik $41,8 \%$. Dan pada aspek strategi regulasi perilaku berkategori cukup baik yaitu $43 \%$. Selanjutnya penelitian Hessy Widiyastuti (2012) diperoleh data tingkat self regulated learning siswa kelas XI SMA Negri 10 Nagreg pada tahun pelajaran 2011/20112 sebanyak 2,73\% berada pada kategori tinggi 15,4\%, kategori sedang $46,36 \%$ tingkat rendah $35,45 \%$. Data hasil penelitian di atas memberikan gambaran bahwa masih banyak siswa yasng memiliki self regulated learning yang rendah.

Fenomena diatas menunjukan bahwa ada siswa yang masih belum bisa mengatur, mengelola, dan mengoptimalkan segala potensi dan kesempatan yang ada pada dirinya menuju keberhasilan belajarnya. Siswa yang memiliki kemampuan self regulation dalam belajar mempunyai keyakinan akan kecerdasan yang mereka miliki dan kegagalan serta kesuksesan mereka sangat bergantung pada usaha mereka dalam menyelesaikan tugas berdasarkan penggunaan strategi yang mereka pilih (Wolters, 2003:59).

Self-Regulated Learning adalah proses aktif dan konstruktif siswa dalam menetapkan tujuan untuk proses belajarnya dan berusaha untuk memonitor, meregulasi, dan mengontrol kognisi, motivasi dan perilaku, yang kemudian semuanya diarahkan dan didorong oleh tujuan dan mengutamakan konteks lingkungan. Siswa yang mempunyai Self regulated learnning tinggi adalah siswa yang secara metakognitif, motivasional, dan behavioral merupakan peserta aktif dalam prosses belajar.

Fakta dilapangan dari hasil Pengamatan dan wawancara yang peneliti lakukan dengan 5 orang Guru BK, Guru Mata Pelajaran, Wali kelas Pada tanggal 01 Desember 2016 dan selama Penulis melaksanakann Praktek Pengenalan Lapangan (PPL) di SMA N 7 Padang diketahui beberapa siswa kurang memahami cara belajar yang efektif, kurang bisa membagi waktu belajar, peserta didik keluar masuk kelas ketika jam pelajaran sedang berlangsung, beberapa peserta didik bercerita ketika guru sedang menjelaskan Pelajaran, Sulit berkosentrasi ketika sedang belajar, beberapa siswa terlihat tidur ketika jam pelajarn sedang berlangsung, menggunakan handphone ketika jam pelajaran sedang berlangsung, tidak mengerjakan tugas tepat waktunya, tidak mengumpul tugas pada waktu yang sudah ditentukan, siswa tidak dapat mengatur waktu belajar dengan baik, siswa tidak dapat memanfaatkan sumber - sumber pelajaran yang ada.

Rendahnya self regulated learning siswa bukanlah suatu hal yang layak dibiarkan. Siswa perlu difasilitasi ataupun diberi kesempatan untuk mengembangkan self regulated learning dalam diri mereka agar mereka memiliki keyakinan diri dan motivasi instrinsik di dalam belajar, maupun menggunakan strategi belajar efektif, dan mampu mengevaluasi keberhasilan dan kegagalan dalam mencapai tujuan belajar. Pada akhirnya, siswa dapat menerima materi pelajaran dengan baik dan hasil belajar mereka menjadi optimal serta berdampak pada kecapaian standar kompetensi kelulusan dari pemerintah.

Berdasarkan permasalahan yang telah dikemukakan di atas maka tidak hanya menjadi tanggung jawab guru mata pelajaran dan wali kelas tetapi juga tanggung jawab guru Bimbingan dan Konseling (BK) yang 
sangat berperan dalam membantu mengentaskan permasalahan - permasalahan yang dihadapi oleh siswa. Melalui layanan bimbingan dan konseling yang diberikan di sekolah meliputi layanan informasi, orientasi, penempatan dan penyaluran, pembelajaran (Penguasaan Konten), bimbingan kelompok, konseling kelompok, dan konseling individu. Pelaksanaan layanan dapaat diberikan dalam format pribadi, kelompok ataupun klasikal.

Berdasarkan hasil wawancara peneliti dengan lima orang Guru BK di SMAN 7 Padang Pada tanggal 01 Desember 2016 terungkap bahwa Guru BK memberikan layanan penguasaan konten dengan cara tanya jawab. Idealnya dalam pelaksanaan layanan konseling secara klasikal dapat menggunakan berbagai pendekatan agar siswa tidak merasa bosan atau jenuh mengikuti kegiatan layanan konseling secara klasikal.

Berkaitan dengan permasalahan yang terjadi di atas, maka peneliti tertarik untuk melakukan penelitian melalui layanan Bimbingan dan Konseling. Tujuan layanan Bimbingan dan Konseling adalah untuk membantu permasalahan yang dialami individu serta membantu individu memperkembangkan potensi secara optimal. Selain bersifat membantu individu secara langsung. Layanan Bimbingan dan Konseling juga bersifat pengembangan. Salah satu layanan yang bersifat mengembangkan adalah layanan penguasaan konten. Layanan penguasaan konten adalah layanan bimbingan dan konseling yang membantu siswa untuk menguasai konten atau keterampilan tertentu. Adapun tujuan Layanan penguasan konten adalah di kuasainya konten tertentu oleh siswa.

Layanan penguasaan konten adalah layanan yang membantu peserta didik menguasai konten tertentu, terutama kompetisi dan atau kebiasaan yang berguna dalam kehidupan di sekolah, keluarga, dan masyarakat (Depdiknas, 2003). Menurut Dewa ketut Sukardi (2003:39) Layanan penguasaan konten dimaksudkan untuk memungkinkan siswa memahami dan mengembangkan sikap dan kebiasaan belajar yang baik, keterampilan dan materi belajar yang cocok dengan kecepatan dan kesulitan belajarnya, serta tuntutan kemampuan yang berguna dalam kehidupan dan perkembangan dirinya.

Pada pelaksanaan penelitian ini dilakukan secara klasikal dengan memberikan beberapa materi yang berkaitan dengan pengaturan diri dalam belajar setelah itu siswa dapat mempraktikan secara langusng dari materi yang telah diberikan. Memberikan pemahaman tentang terhadap cara merencanakan dan mengelola jabwal belajar secara konsisten dan evaluatif. Oleh karena itu, melalui layanan penguasaan konten hal - hal yang mengganggu dapat dilonggarkan melalui berbagai teknik dengan wawasan yang diperluas melalui pembelajaran. Melalui kondisi dan proses pemberian wawasan yang terarah dan luas usaha belajar siswa dapat dikembangkan.

Layanan penguasaan konten dipilih karena tujuan dari layanan ini adalah untuk memahami dan mengembangkan sikap dan kebiasaan yang baik bagi siswa agar mendapatkan keterampilan baru dan memperkuat perilaku yang sudah ada sehingga siswa dapat melatih perilaku yang sudah ada dengan perilaku baru baik dirumah maupun disekolah.

Dalam pelaksanaan Layanan Penguasaan konten diberikan layanan secara klasikal dengan menggunakan strategi problem solving. Problem solving adalah suatu proses belajar mengajar yang berupa penghilangan perbedaan atau ketidak sesuaian yang terjadi antara hasil yang diperoleh dengan yang diinginkan. (Pranata 2005: 3) sejalan dengan pendapat Prawiro (1986:36) problem solving adalah metode mengajar dengan jalan menghadapkan siswa pada suatu masalah yang harus dipecahkan oleh siswa sendiri dengan mengarahkan segala kemampuan yang ada pada siswa tersebut.

Berdasarkan temuan penelitian Romarta (2016) yang berjudul efektifitas layanan informasi dengan metode problem solving untuk meningkatkan kontrol diri siswa yaitu : (1) terdapat perbedaan yang signifikan peningkatan kontrol diri siswa sebelum dan sesudah mengikuti layanan informasi dengan metode problem solving pada kelompok eksperimen, (2) tidak terdapat perbedaaan yanng signifikan peningkatan kontrol diri siswa pada kelompok kontrol, (3) terdapat perbedaan yang signifikan peningkatan kontrol pada kelompok eksperimen dengan kelompok kontrol. Berdasakan temuan di atas, dapat disimpulkan bahwa kontrol diri siswa dapat ditingkat melalui layanan informasi dengan metode problem solving, oleh karena itu guru BK disarankan dapat mengembangkan layanan bimbingan dan konseling terutama layanan informasi untuk membantu meningkatkan kontrol diri siswa.

Santrock (2012:316) problem solving (pemecahan masalah) adalah mencari cara yang tepat untuk mencapai suatu tujuan. Ada empat langkah dalam memecahkan masalah yaitu (1) mencari dan memahami masalah, (2) menyusun strategi pemecahan masalah yang baik, (3) mengeksplorasi solusi, (4) memikirkan dan mendefinisikan kembali problem dan solusi dari waktu ke waktu. Selain itu metode problem solving atau pemecahan masalah juga berguna untuk merangsang berpikir situasi masalah yang komplek.

Dengan demikian dapat diasumsikan bahwa melalui layanan penguasaan konten dengan menggunakan pendekatan problem solving dapat mempengaruhi Self-Regulated learning siswa dengan memberikan pemahaman tentang pengaturan diri dalam belajar dan dampak pengaturan diri dalam belajar melalui pemberian materi - materi dari layanan penguasaan konten dengan teknik problem solving. sehingga 
siswa dapat membentuk sikap dan kebiasaan baru dengan mengembangkan ide kreatifitas dan melatih sikap dan kebiasaan yang sudah ada agar proses belajar mengajarnya dapat berjalan secara efektif.

Dengan latar belakang masalah diatas maka peneliti tertarik untuk meneliti Efekttifitas Layanan Penguasaan konten menggunakan strategi Problem solving untuk meningkatkan Self-Regulated Learning siswa kelas XI IPS di SMA N 7 Padang.

\section{Metode}

penelitian ini merupakan penelitian Quasi Eksperiment. Menurut Trianto (2011:203) penelitian eksperimen dapat didefinisikan sebagai metode sistematis guna membangun hubung an yang mengandung fenomena sebab akibat. Menurut Punaji Setyosari (2013:183) rancangan penelitian eksperimen kuasi dalam kaitannya dengan pemilihan subjek penelitian, peneliti tidak selalu dapat melakukan pemilihan subjek secara random. Sejalan dengan itu menurut Sumadi Suryabrata (2012:92) tujuan Quasi Experiment atau eksperimen semu adalah untuk memperoleh informasi yang merupakan perkiraan bagi informasi yang dapat diperoleh dengan eksperimen yang sebenarnya dalam keadaan yang tidak memungkinkan untuk mengontrol dan/atau memanipulasikan semua variabel yang relevan.

Penelitian eksperiman ini menggunakan desain "The Non Equivalent Control Group". Rancangan kelompok non ekuivalen menurut A. Muri Yusuf (2013:185) bahwa rancangan the non equivalent control group diambil tidak secara random, baik untuk kelompok eksperimen maupun kelompok kontrol.

Subjek penelitian meliputi kelas XI IPS 2 sebagai kelas kontrol dan kelas XI IPS 3 SMAN 7 Padang sebagai kelompok eksperimen. Untuk mengumpulkan data, digunakan instrumen penelitian berupa angket untuk pretest dan untuk posttest dengan alternative jawaban Selalu (SL), Sering (SR), Kadang-kadang (KD), Jarang (JR), dan Tidak Pernah (TP). Untuk melihat perbandingan nilai Pretest dan Posttest yang dikemukakan oleh Suharsimi Arikunto (2010:395), dengan langkah-langkah sebagai berikut.

1. Melaksanakan Pretest (O1), cari skor dan rata-rata hitungnya.

Jumlah skor ideal $=$ skor tertinggi $\mathrm{x}$ jumlah item angket $\mathrm{x}$ sampel

$$
\mathrm{P}=\frac{f}{N} \mathrm{X} 100
$$

Keterangan :

$\mathrm{P}:$ Persentase

$F$ : Frekuensi

$\mathrm{N}$ : Jumlah sampel

2. Setelah data diolah menggunakan rumus statistik kemudian diterapkan kriteria penilaian masingmasing data yang diperoleh dengan mengacu pada batasan-batasan yang dikemukakan oleh Agus Irianto (2004:22) dengan rumus sebagai berikut.

$$
\text { Interval }_{\mathrm{k}}=\frac{\text { Data terbesar }- \text { data terkecil }}{\text { Jumlah kelompok }}
$$

Berdasarkan hasil perhitungan yang telah dilakukan, kemudian ditetapkan kriteria penilaian masingmasing data yang diperoleh, yang mengacu pada batasan yang dikemukakan oleh Anas Sudijono (2009:329):

Tabel 1. Kriteria Pengolahan Data Deskripti

\begin{tabular}{ccc}
\hline Kelas Interval & Kategori & \% Skor Keseluruhan \\
\hline $133-160$ & Sangat Tinggi & $81-100$ \\
$106-132$ & Tinggi & $67-83$ \\
$79-105$ & Sedang & $51-66$ \\
$78-53$ & Rendah & $36-50$ \\
$\leq 52$ & Sangat Rendah & $\leq 31$ \\
\hline
\end{tabular}

Selanjutnya, untuk menguji perbedaan Self regulated learning sebelum dan setelah diberikan perlakuan, maka digunakan uji t atau t-test. Tulus Winarsunu (2002:87) menyatakan untuk menguji signifikansi perbedaan dua buah mean yang berasal dari dua buah distribusi adalah dengan menggunakan teknik t-test dengan rumus sebagai berikut. 
Keterangan,

$$
t \text { test }=\frac{\bar{X}_{1}-\bar{X}_{2}}{\sqrt{\left[\frac{S D_{1}^{2}}{N_{1}-1}\right]+\left[\frac{S D_{2}^{2}}{N_{2}-1}\right]}}
$$

$\bar{X}_{1} \quad$ : Mean tingkat self regulated learning siswa eksperimen

$\bar{X}_{2} \quad$ : Mean tingkat self regulated learning siswa kontrol

$S D_{1}^{2} \quad$ : Nilai varian tingkat self regulated learning siswa eksperimen

$S D_{2}^{2} \quad$ : Nilai varian tingkat self regulated learning siswa kontrol

$N_{1} \quad$ : Jumlah sampel siswa eksperimen

$N_{2} \quad$ : Jumlah sampel siswa kontrol

Hasil perhitungan tersebut dibandingkan dengan $t_{\text {tabel. }}$ Jika $t_{\text {hitung }}$ kecil dari $t_{\text {tabel }}$ maka dapat disimpulkan bahwa terdapat perbedaan yang signifikan antara pre-test dan post-test.

\section{Hasil Penelitian}

Untuk menganalisis hasil penelitian, peneliti menggunakan teknik uji beda (t-test) dengan bantuan program SPSS versi 20.00 dan Microsoft Excell 2007.

\section{Pengujian Hipotesis Pertama}

Hipotesis pertama yang diajukan dalam penelitian ini adalah terdapat perbedaan yang signifikan pada self regulated learning siswa kelompok eksperimen sebelum dan sesudah diberikan layanan penguasaan konten menggunakan strategi problem solving, yang hasil perhitungannya dapat dilihat pada tabel berikut ini.

Tabel 2. Distribusi Frekuensi Pretest dan Posttest Self regulated learning siswa Kelompok Eksperimen

\begin{tabular}{|c|c|c|c|c|c|}
\hline \multirow{2}{*}{ Interval } & \multirow{2}{*}{ Kategori } & \multicolumn{2}{|r|}{ Pretest } & \multicolumn{2}{|l|}{ Posttest } \\
\hline & & $\bar{F}$ & $\%$ & $\bar{F}$ & $\%$ \\
\hline $133-160$ & Sangat tinggi & 0 & 0 & 1 & 4 \\
\hline 106-132 & Tinggi & 1 & 4 & 7 & 25 \\
\hline $79-105$ & Sedang & 10 & 36 & 20 & 71 \\
\hline $78-53$ & Rendah & 17 & 64 & 0 & 0 \\
\hline$\leq 52$ & Sangat rendah & 0 & 0 & 0 & 0 \\
\hline & Jumlah & 28 & 100 & 28 & 100 \\
\hline
\end{tabular}

Selanjutnya, untuk melihat kondisi masing-masing self regulated learning siswa pada pretest dan posttest kelompok eksperimen dapat digambarkan pada diagram berikut.

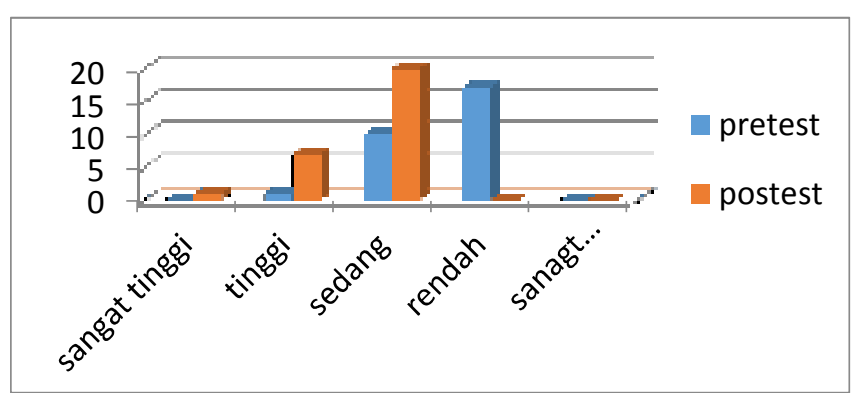

Gambar 1. Diagram Hasil Pretest dan Posttest Self Regulated Learning Siswa Kelompok Eksperimen Sementara itu, berdasarkan hasil uji beda ( $t$-test) diperoleh hasil sebagai berikut:

Tabel 3. Hasil Analisis Uji T-Test Perbedaan Self Regulated Learning siswa pada Pretest dan Posttest Kelompok Eksperimen

\begin{tabular}{lcccccc}
\hline Self & $\begin{array}{c}\text { Pretest dan } \\
\text { posttest }\end{array}$ & Mean & $\begin{array}{c}\text { Std. } \\
\text { Deviation }\end{array}$ & T & Df & Sig. (2- tailed) \\
\cline { 2 - 7 } $\begin{array}{l}\text { regulated } \\
\text { learning }\end{array}$ & $\begin{array}{l}\text { Pretest } \\
\text { Posttest }\end{array}$ & 112.04 & 16.047 & -6.135 & & \\
& Pos.43 & 13.604 & & 54 & .000
\end{tabular}

Dari hasil perhitungan tersebut diperoleh nilai Asymp. Sig. (2-tailed) lebih kecil dari taraf signifikansi 0.05 $(0.000<0.05)$. Dengan demikian, hipotesis pertama pada penelitian ini dapat diterima, yakni terdapat 
perbedaan yang signifikan pada self regulated learning kelompok eksperimen sebelum dan sesudah diberi layanan penguasaan konten menggunakan strategi problem solving.

\section{Pengujian Hipotesis Kedua}

Hipotesis kedua, yaitu tidak terdapat perbedaan yang signifikan pada self regulated learning siswa kelompok kontrol sebelum dan sesudah diberikan perlakuan layanan penguasaan konten tanpa menggunakan metode problem solving. yang hasil perhitungannya dapat dilihat pada tabel berikut ini.

Tabel 4. Distribusi Frekuensi Pretest dan Posttest self regulated learning Siswa Kelompok Kontrol

\begin{tabular}{clcccc}
\hline Interval & Kategori & \multicolumn{3}{c}{ Pretest } & \multicolumn{2}{c}{ Posttest } \\
\cline { 3 - 6 } & & $\mathrm{F}$ & $\%$ & $\mathrm{~F}$ & $\%$ \\
$133-160$ & Sangat tinggi & 0 & 0 & 0 & 0 \\
$106-132$ & Tinggi & 4 & 14 & 6 & 21 \\
$79-105$ & Sedang & 12 & 43 & 21 & 75 \\
$78-53$ & Rendah & 12 & 43 & 1 & 4 \\
$\leq 52$ & Sangat rendah & 0 & 0 & 0 & 0 \\
& Jumlah & 28 & 100 & 28 & 100
\end{tabular}

Selanjutnya, untuk melihat kondisi masing-masing self regulated learning siswa dalam belajar pada pretest dan posttest kelompok kontrol dapat digambarkan pada diagram berikut.

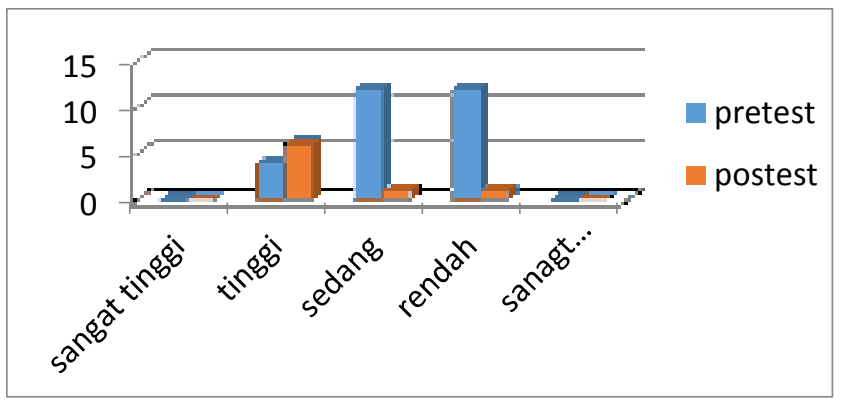

Gambar 2. Diagram Distribusi Frekuensi Pretest dan Posttest Self Regulated learning Siswa pada Kelompok Kontrol

Sementara itu, berdasarkan hasil uji beda (t-test) diperoleh hasil sebagai berikut.

Tabel 5. Hasil Analisis Uji t-test Perbedaan Self Regulated Learning Siswa pada Pretest dan Posttest Kelompok Kontrol

\begin{tabular}{|c|c|c|c|c|c|c|}
\hline Self & $\begin{array}{c}\text { Pretest dan } \\
\text { posttest }\end{array}$ & Mean & $\begin{array}{c}\text { Std. } \\
\text { Deviation }\end{array}$ & $\mathbf{T}$ & $\overline{\text { Df }}$ & Sig. (2- tailed) \\
\hline regulated & Pretest & 122.36 & 16.209 & 1.341 & & \\
\hline learning & Posttest & 127.61 & 12.796 & & 51 & .0 .186 \\
\hline
\end{tabular}

Dari hasil perhitungan tersebut diperoleh nilai Asymp. Sig. (2-tailed) lebih besar dari taraf signifikansi $5.25(0.186>0.05)$. Dengan demikian, hipotesis kedua pada penelitian ini dapat diterima, yakni tidak terdapat perbedaan yang signifikan pada self regulated learning siswa dalam belajar pada kelompok kontrol sebelum dan sesudah diberi perlakuan.

\section{Pengujian Hipotesis Ketiga}

Hipotesis ketiga yang diajukan dalam penelitian ini adalah terdapat perbedaan yang signifikan pada self regulated learning siswa antara kelompok eksperimen yang mengikuti layanan penguasaan konten menggunakan metode problem solving dan self regulated learning kelompok kontrol yang mengikuti layanan penguasaan konten tanpa menggunakan metode problem solving, yang hasil perhitunganya dapat dilihat pada 
Tabel 6. Distribusi Frekuensi Posttest

Self Regulated Learning siswa dalam belajar

Kelompok Eksperimen dan kelompok Kontrol

\begin{tabular}{|c|c|c|c|c|c|}
\hline \multirow[t]{2}{*}{ Interval } & \multirow[t]{2}{*}{ Kategori } & \multicolumn{2}{|c|}{ Frekuensi } & \multirow[b]{2}{*}{$\mathrm{N}$} & \multirow[b]{2}{*}{$\%$} \\
\hline & & Eksperimen & Kontrol & & \\
\hline $133-160$ & Sangat tinggi & 1 & 0 & 0 & 0 \\
\hline 106-132 & Tinggi & 7 & 6 & 13 & 56.25 \\
\hline $79-105$ & Sedang & 20 & 21 & 41 & 37.5 \\
\hline $78-53$ & Rendah & 0 & 1 & 1 & 6.25 \\
\hline$\leq 52$ & Sangat rendah & 0 & 0 & 0 & 0 \\
\hline \multirow[t]{2}{*}{ Jumlah } & & 28 & 28 & & \\
\hline & & & & 73 & 100 \\
\hline
\end{tabular}

Untuk lebih jelasnya dapat dilihat pada diagram berikut :

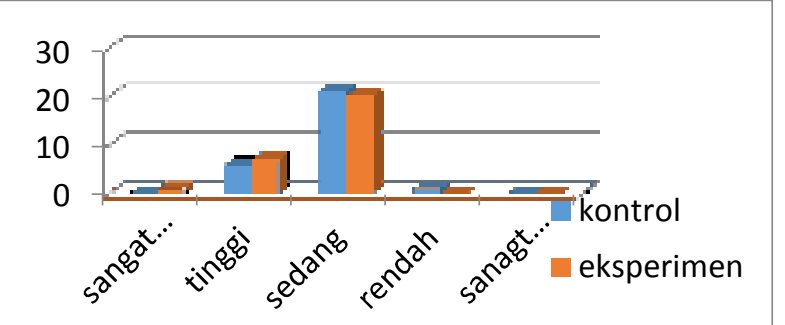

Gambar 3. Diagram Hasil Posttest Self Regulated Learning siswa pada Kelompok Eksperimen dan Kelompok Kontrol

Sementara itu, berdasarkan hasil uji beda (t-test) diperoleh hasil sebagai berikut:

Tabel 7. Hasil Analisis Uji t-test Perbedaan Self Regulated learning Siswa pada Kelompok Ekperimen dan Kelompok Kontrol Sesudah Diberikan Perlakuan

\begin{tabular}{ccccccc}
\hline Self regulated & Posttest & Mean & $\begin{array}{c}\text { Std. } \\
\text { Deviation }\end{array}$ & T & Df & $\begin{array}{c}\text { Sig. (2- } \\
\text { tailed) }\end{array}$ \\
\cline { 2 - 7 } & Eksperimen & 39.80 & 136.43 & -2.499 & 54 & .000 \\
& Kontrol & 27.91 & 127.61 & & &
\end{tabular}

Dari hasil perhitungan tersebut diperoleh nilai Asymp. Sig. (2-tailed) lebih kecil dari taraf signifikansi $0.05(0.016>0.05)$. Dengan demikian, hipotesis ketiga pada penelitian ini dapat diterima, yakni terdapat perbedaan yang signifikan pada self regulated learning siswa antara kelompok eksperimen yang mengikuti layanan penguasaan konten menggunakan metode problem solving dan self regulated learning siswa kelompok kontrol yang mengikuti layanan penguasaan konten tanpa menggunakan metode problem solving.

\section{PEMBAHASAN}

Pada bagian ini akan dikemukakan pembahasan hasil temuan peneliti mengenai self reulated learning siswa dalam belajar melalui layanan penguasaan konten menggunakan metode problem solving.

\section{Perbedaan Self Regulated Learning siswa Kelompok Eksperimen (Pretest dan Posttest)}

Berdasarkan pengujian hipotesis pertama, dapat disimpulkan bahwa terdapat perbedaan yang signifikan pada self regulated learning siswa dalam belajar pada kelompok eksperimen sebelum dan sesudah diberikan layanan penguasaan konten menggunakan strategi problem solving, yakni terjadi pengurangan yang signifikan perilaku menyontek siswa saat ujian kelompok eksperimen setelah diberikan perlakuan. Perilaku menyontek menurut zimerman (2004) mendefenisikan self regulated learning sebagai kemampuan siswa untuk berpartisipasi aktif dalam proses belajarnya, baik secara metakognitif, individu yang meregulasi diri merencanakan, mengorganisasikan, mengintruksi diri, memonitor dan mengevaluasi dirinya dalam proses belajar. secara motivasional dan secara behavioral. Secara metakognitif individu yang belajar merasa bahwa dirinya kompeten, memliki keyakinan diri (Self efficacy)dan memiliki kemandirian sedangkan secara behavioral, individu yang belajar menyeleksi, menyusun, dan menata lingkungan agar optimal dalam belajar.

Self regulated learning yang dimaksud adalah proses aktif konstruktif siswa dalam menetapkan tujuan proses belajarnya dan berusaha untuk memonitor, meregulasi,dan mengontrol kognisi, motivasi dan perilaku, yang kemuudian semuanya diarahkan dan didorong oleh tujuan dan mengutamakan konteks 
likungan. Siswa yang mempunyai self regulated learning tinggi adalah siswa yang secara metakognitif, motivasional, dan behavioral merupakan peserta aktif dalam proses belajar.

Meningkatkan self regulated learning siswa dalam belajar merupakan salah satu tugas dan tanggung jawab guru BK atau konselor sekolah. Adapun bantuan yang diberikan dapat melalui layanan BK, diantaranya melalui layanan penguasaan konten. Pemberian layanan penguasaan konten (PKO) merupakan layanan bantuan kepada individu (sendiri ataupun kelompok) untuk menguasai kemampuan atau kompetensi tertentu melalui kegiatan belajar (Prayitno, 2012:89).

Pada penelitian ini, Layanan penguasaaan konten menggunakan strateggi problem solving yang dilaksanakan adalah dengan cara klasikal dalam satu kelas. Kemudian peneliti menjelaskan permasalahan atau materi yang akan dibahas lalu siswa diminta untuk memecahkan permasalahan tersebut dan kemudian siswa diminta menuliskan permasalahan yang telah di pecahkkan dalam buku latihan berupa konten- konten yang bisa diterapkan dalam kehidupan sehari-hari.

Keberhasilan pemberian layanan penguasaan konten menggunakan strategi problem solving diperkuat dengan hasil temuan pada hipotesis pertama yang menyatakan bahwa terdapat perbedaan yang signifikan self regulated learning kelompok eksperimen sebelum dan sesudah diberikan layanan penguasaan konten menggunakan strategi problem solving.

Berdasarkan hal yang telah dijelaskan di atas, maka layanan penguasaan konten menggunakan strategi problem solving dapat diberikan dalam rangka meningkatkan self regulated learning siswa dalam belajar. Dengan adanya layanan penguasaan konten menggunakan strategi problem solving menjadikan siswa paham akan pentingnya meningkatkan self regulated learning.

\section{Perbedaan Self regulated learning siswa Kelompok Kontrol (Pretest dan Posttest)}

Pemberian layanan penguasaan konten untuk meningkatkan self regulated learning pada kelompok kontrol dilakukan tanpa menggunakan strategi problem solving. Dari data hasil penelitian, diketahui bahwa tidak terdapat perbedaan yang signifikan pada perilaku menyontek siswa saat ujian kelompok kontrol sebelum dan sesudah diberi perlakuan. Dikatakan tidak signifikan karena hanya terjadi perbedaan mean sebelum dan sesudah diberi perlakuan, sementara tidak terjadinya perbedaan kategori. Perubahan tersebut dikarenakan kelompok kontrol tidak mendapat perlakuan khusus yaitu layanan penguasaan konten menggunakan strategi problem solving.

Layanan penguasaan konten dalam menigkatkan self regulated learning siswa dalam belajar kelompok kontrol diberikan secara konvensional, yaitu teknik ceramah dan tanya jawab. Senada dengan pernyataan tersebut, metode atau teknik yang digunakan dalam penyajian layanan penguasaan konten menurut Prayitno (2012:97) adalah penyajian, tanya jawab dan diskusi.

Pemberian layanan penguasaan konten secara konvensional atau tanpa menggunakan strategi problem solving belajar ini menyajikan materi yang sama diberikan pada kelas eksperimen. Pada hasil penelitian ini tergambarlah bahwa kurang efektifnya pemberian layanan penguasaan konten secara konvensional. Hal ini didukung dengan hasil penelitian yang menunjukan tidak adanya perubahan signifikan sebelum dan setelah diberikan perlakuan layanan penguasaan konten pada kelas kontrol.

\section{Perbedaan self regulated learning siswa Kelompok Eksperimen dan Kelompok Kontrol (Posttest)}

Tujuan dari penelitian ini adalah untuk mengetahui perbedaan efektivitas layanan penguasaan konten menggunakan strategi problem solving pada kelompok eksperimen dan layanan penguasaan konten secara konvensional pada kelompok kontrol untuk meningkatkan self regulated learning siswa dalam belajar. Hasil penelitian menunjukan bahwa terdapat perbedaan yang signifikan pada self regulated learning siswa yang diberi layanan penguasaan konten menggunakan strategi problem solving dengan kelompok kontrol yang diberi layanan penguasaan konten secara konvensional.

Berdasarkan hasil uji statisitik menunjukan adanya perbedaan self regulated learning siswa saat ujian pada kelompok eksperimen dan kelompok kontrol. Perbedaan self regulated learning siswa dalam belajar terjadi karena adanya perbedaan perlakuan yang diterima oleh masing-masing kelompok. Meskipun materi dan banyaknya perlakuan yang diberikan sama-sama berjumlah 4 kali. Kelompok kontrol diberikan perlakuan berbeda dari kelompok ekperimen yaitu pemberian layanan penguasaan konten secara konvensional atau tanpa strategi problem solving. Peneliti memberikan materi dan konten-konten mengenai self regulated learning siswa daalam belajar dengan teknik ceramah dan tanya jawab. Kemudian peneliti mempersilahkan siswa untuk bertanya apabila terdapat hal yang belum dipahami. Selama proses pembelajaran berlangsung, tidak banyak siswa yang merespon pertanyaan dari peneliti. Siswa yang aktif biasanya selalu sama pada setiap pertemuan, dan sulit untuk mendorong siswa yang lain untuk ikut aktif.

Selanjutnya, untuk kelompok eksperimen diberikan perlakuan layanan penguasaan konten menggunakan strategi problem solving. Dalam pelaksanaan pembelajaran, guru hendaknya dapat membantu siswa untuk lebih mudah memahami pelajaran dan melibatkan siswa untuk lebih aktif serta menjadikan proses pembelajaran sebagai hal yang menyenangkan. Begitupun untuk guru Bimbingan dan Konseling, 
yang juga dapat lebih inovatif untuk menggunakan media, model ataupun strategi pembelajaran dalam pemberian layanan. Layanan penguasaan konten yang diberikan guru BK bertujuan agar siswa menguasai aspek-aspek konten (kemampuan atau kompetensi) tertentu yang berguna untuk menambah wawasan dan pemahaman, mengarahkan penilaian dan sikap, menguasai cara-cara tertentu dalam rangka memenuhi kebutuhan dan mengatasi masalah-masalahnya (Tohirin, 2011:159).

Pemilihan model pembelajaran perlu didasari oleh kesesuaian tujuan dari pembelajaran itu sendiri. Model pembelajaran bimbingan kelompok belajar merupakan salah satu model dalam pembelajaran yang mengajak siswa untuk belajar secara kelompok turut pula merealisasikan tujuan pendidikan dan pengajaran dan untuk belajar mengatasi kesullitan secara bersama-sama, terutama dalam hal pelajaran.

\section{KESIMPULAN}

Berdasarkan hasil penelitian yang diperoleh, dan setelah melakukan analisis statistik, serta pengujian hipotesis, maka secara umum dapat disimpulkan bahwa layanan penguasaan konten menggunakan strategi problem solving dapat meningkatkan self regulated learning siswa dalam belajar. Secara khusus temuan dalam penelitian ini adalah sebagai berikut :

1. Terdapat perbedaan yang signifikan pada self regulated learning siswa dalam belajar kelompok eksperimen sebelum dan sesudah diberikan layanan penguasaan konten menggunakan strategi problem solving.

2. Tidak terdapat perbedaan yang signifikan pada self regulated learning siswa dalam belajar kelompok kontrol sebelum dan sesudah diberikan perlakuan layanan penguasaan konten tanpa menggunakan strategi problem solving.

3. Terdapat perbedaan yang signifikan pada self regulated learning siswa dalam beajar antara kelompok eksperimen yang mengikuti layanan penguasaan konten menggunakan strategi problem solving dan self regulated learning siswa kelompok kontrol yang mengikuti layanan penguasaan konten tanpa menggunakan strategi problem solving.

Hasil pengujian ketiga hipotesis dalam penelitian ini menunjukan bahwa layanan penguasaan konten menggunakan strategi problem solving lebih efektif dalam meningkatkan self regulated learning siswa dalam belajar. Layanan penguasaan konten secara konvensional dapat meningkatkan self regulated learning siswa dalam belajar, namun peningkatan rata-rata skor tidak sebanyak pada layanan penguasaan konten menggunakan strategi problem solving.

\section{Kepustakaan}

Agus Irianto. 2004. Statistik: Konsep Dasar, Aplikasi dan Pengembangannya. Jakarta: Renada Media Group

Depdiknas. 2005. Naskah Layanan Orientasi dan Informasi, Penempatan dan Penyaluran, Layanan Pembelajaran Sekolah Menengah Pertama (SMP). Jakarta: Depdiknas

Dewa Ketut Sukardi. 2010. Pengantar Pelaksanaan Program Bimbingan dan Konseling di Sekolah. Jakarta: Rineka Cipta

Duwi Pyaritno. 2012. Cara Kiat Belajar Analisis Data dengan SPSS 20. Yogyakarta: Andi Offset.

Eka Wahyuni dan Gantina Komalasari. 2011. Teori dan Teknik Konseling. Jakarta: Pt. Indeks

Hamzah B. Uno. 2008. Model Pembelajaran. Jakarta : PT Bumi Aksara

J.W. Santrock. 2012. Adolescence (Perkembangan Remaja). Jakarta: Erlangga.

Jakarta: Kloang Klede.

Montalvo, F.T., Torres, M.C.G. 2004. "Self-Regulated Learning: Current and future directions. Spain: Departement of education: University de navarra". Journal of Educational Psychology, (online), Vol. 54 (1), No. 2, Hal. 1-34, (http://investigacion.org/articulos/3/english, diakses 4 April 2015).

Ngalimun. 2013. Strategi dan Model Pembelajaran. Yogyakarta: Aswaja Pressindo.

Nuzliah. 2015. "Kontribusi Motivasi Belajar, Kreativitas terhadap Problem Solving (Pemecahan Masalah) Siswa di SMPN 29 Padang" tesis. Padang : BK FIP UNP.s 
Peter Salim \& Yenny, S. 1991. Kamus Besar Bahasa Indonesia Kontemporer. Jakarta: Modern English Press.

Prayitno. 1997. Seri Pemandu Pelaksanaan Bimbingan dan Konseling di Sekolah. Padang: BK FIP UNP.

Prayitno. 2012. Jenis Layanan dan Kegiatan Pendukung Konseling. Padang: BK FIP UNP.

Riduwan. 2013. Skala Pengukuran Variable-variabel Penelitian. Bandung: Alfabeta

Romarta fitri yana. 2016. "efektifitas layanan informasi dengan metode problem solving terhadap peningkatan kontrol diri siwa”. Skripsi. Tidak diterbitkan. Padang : BK FIP UNP.

Schunk, H. D. 2005. Self regulated learning: The educational legacy of Paul R. Pintrich. Educational Psychologist, Vol. 40, No. 2, Hal. 85-94.

Sedarmayanti. 2009. Sumber Daya Manusia dan Produktifitas Kerja. Jakarta: Rineka Cipta.

Subran. A. A. 2001. "Self Regulated Learning and Academic Achievement of Hongkong and Indian High School Students". Disertasi. University of Hong Kongkong.

Syaiful Bahri Djamarah. 2002. Rahasia Sukses Belajar. Jakarta : Rineka Cipta.

Tulus Winarsunu. 2002. Statistik dalam Penelitian Psikologi dan Pendidikan. Malang: UMM Press.

Wena. 2013. Strategi Pembelajaran Inovatif Kontemporer. Jakarta: Bumi Aksara.

Winne, P.H. 1997. "Experimenting to Bootstrap Self-Regulated Learning". Journal of Educational

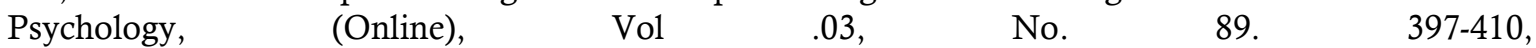
(ftp://ftp.uwc.ac.za/users/DMS/CITI/bootstrapping.pdf/, diakses 04 April 2015).

Yusuf, A. 2013. Metode Penelitian Kuantitatif, Kualitatif dan Penelitian gabungan. Padang: UNP Press.

Zimmerman dan Pons. 1990. "Student Differences in Self Regulated Learning: Relating grade, sex, and giftedness to self eficacy and strategy use". Journal of Educational qqPsychology, Vol. 82, No 1, Hal 51-59.

Zimmerman. 1990. "Self Regulated Learning adn Academic Achievement: An overview". Journal of Educational Psychologist. Vol. 25, No. 1, Hal. 3-17.

Zimmerman. 2002. "Becoming a Self Regulated Learner: An overview". Theory Into Practice, Vol. 41, No. 2, Hal. 64-70. 